Nauki ekonomiczne w XXI wieku - wyzwania, dylematy, perspektywy

ISSN 1899-3192

Międzynarodowe stosunki gospodarcze

\title{
Krzysztof Falkowski
}

Szkoła Główna Handlowa w Warszawie

e-mail: kfalkow@sgh.waw.pl

\section{KONSEKWENCJE „KLĄTWY SUROWCOWEJ” DLA MIĘDZYNARODOWEJ KONKURENCYJNOŚCI AZERBEJDŻANU, KAZACHSTANU ORAZ ROSJI}

\section{EFFECTS OF THE RESOURCE CURSE FOR THE INTERNATIONAL COMPETITIVENESS OF AZERBAIJAN, KAZAKHSTAN AND RUSSIA}

DOI: $10.15611 /$ pn.2017.498.07

JEL Classification: F14, O11, Q33, Q37

Streszczenie: Celem artykułu jest odpowiedź na pytanie, w jakim stopniu Azerbejdżan, Kazachstan oraz Rosja - kraje dotknięte zjawiskiem „klątwy surowcowej” - są konkurencyjne w handlu międzynarodowym, a także w jakim stopniu ich profil konkurencyjny jest determinowany przez posiadanie obfitych zasobów surowców mineralnych. W artykule wykorzystano dwa wskaźniki, tj. wskaźnik ujawnionych przewag komparatywnych Balassy (RCA) oraz wskaźnik relacji eksportowo-importowych Lafaya (LFI). Z przeprowadzonej analizy wynika, iż ogólny poziom konkurencyjności Azerbejdżanu, Kazachstanu oraz Rosji w handlu międzynarodowym jest niski, zwłaszcza w zakresie towarów wysokiej oraz średnio-wysokiej techniki, zaś jedyne przewagi komparatywne posiadają one $\mathrm{w}$ eksporcie towarów $\mathrm{z}$ grupy średnio-niskiej techniki. Sytuacja taka jest konsekwencją występującej w tych krajach „klątwy surowcowej”, która skutecznie wzmacniając surowcowy charakter tych gospodarek, obniża ich ogólny poziom międzynarodowej konkurencyjności.

Słowa kluczowe: klątwa surowcowa, konkurencyjność międzynarodowa, handel międzynarodowy, Azerbejdżan, Kazachstan, Rosja.

Summary: The purpose of the article is to investigate how competitive economies of Azerbaijan, Kazakhstan and Russia - the countries afflicted by the so-called resource curse - are in contemporary international trade and to what degree their competitive profiles are determined by their abundant resource bases. To this end, two indicators - Balassa's Revealed Comparative Advantage (RCA) index and the Lafay Index (LFI) of international trade specialization - have been applied. The analysis conducted has shown that the overall international competitiveness of Azerbaijan, Kazakhstan and Russia is low, especially with respect to high- and medium-high-technology goods, with their only comparative advantages lying in exports of low-technology goods. It is the effect of the resource curse affecting these countries, which further reinforces the resource-based character of their economies, thereby lowering their overall international competitiveness.

Keywords: resource curse, international competitiveness, international trade, Azerbaijan, Kazakhstan, Russia. 


\section{Wstęp}

W literaturze ekonomicznej istnieje cały szereg badań nad zjawiskiem tzw. „klątwy surowcowej" (resource curse), rozumianej jako sytuacja, w której kraje obficie wyposażone w zasoby surowców naturalnych, intensywnie je eksploatując, paradoksalnie rozwijają się względnie słabiej aniżeli kraje owych zasobów nieposiadające [Sachs, Warner 2001]. Do powszechnego dyskursu ekonomicznego pojęcie „klątwy surowcowej" wprowadził R. Auty [1993] na początku lat 90. XX wieku. Zdecydowanie najczęściej w prowadzonych badaniach podkreśla się fakt negatywnej korelacji pomiędzy występowaniem bogatych złóż surowców mineralnych a wzrostem gospodarczym danego kraju (m.in. [Humphreys i in. 2007; Gylfason i in. 1999; Sachs, Warner 1995]). Brakuje jednakże badań i analiz dotyczących roli „klątwy surowcowej" w kształtowaniu międzynarodowego profilu konkurencyjnego gospodarek dotkniętych tym zjawiskiem.

W kontekście powyższego ważnym i zarazem niezwykle interesującym zagadnieniem badawczym jawi się próba odpowiedzi na pytanie, w jakim stopniu trzy wybrane gospodarki poradzieckie, dotknięte „klątwą surowcową”, tj. Azerbejdżan, Kazachstan oraz Rosja, są konkurencyjne we współczesnym handlu międzynarodowym, a także w jakim stopniu ich profil konkurencyjny jest determinowany przez fakt posiadania obfitych zasobów surowców mineralnych. Trzeba bowiem podkreślić, iż od tego, czy potrafią one być konkurencyjne nie tylko w eksporcie wspomnianych surowców, ale także w eksporcie towarów zaawansowanych technologicznie, powstających w przemysłach intensywnie wykorzystujących nowoczesne czynniki produkcji i charakteryzujących się wysokim poziomem innowacyjności, co jest szczególnie pożądane w realiach współczesnego świata [Wu i in. 2017], zależy nie tylko obecny, ale także przyszły rozwój tych krajów.

W niniejszym artykule stawia się tezę, że ogólny poziom konkurencyjności Azerbejdżanu, Kazachstanu oraz Rosji w handlu międzynarodowym jest niski, co jest w znacznym stopniu konsekwencją występującej w tych krajach „klątwy surowcowej”, która skutecznie wzmacniając surowcowy charakter ich gospodarek, obniża ogólny poziom międzynarodowej konkurencyjności, a także silnie uzależnia ich dalszy rozwój od koniunktury cenowej na międzynarodowych rynkach surowcowych, zwiększając tym samym podatność na szoki zewnętrzne.

\section{Zastosowana metoda badawcza}

Do oceny poziomu międzynarodowej konkurencyjności gospodarek w handlu międzynarodowym, rozumianej jako zdolność do szybszego (niż inne kraje) osiągania większych korzyści z własnych i zagranicznych czynników produkcji w warunkach otwarcia gospodarki [Weresa (ed.) 2014], sprowadzającej się do umiejętności opracowywania, wytwarzania oraz sprzedaży towarów i usług, bardziej atrakcyjnych cenowo bądź jakościowo od oferty eksportowej innych krajów, czego wymiernym 
wyznacznikiem będzie rosnący udział w handlu międzynarodowym danego kraju w zakresie sprzedaży tych dóbr względem innych krajów [Carbaugh 2017], ekonomiści wykorzystują bardzo różne metody. Ich syntetycznego przeglądu dokonali m.in. Startiene, Remeikiene [2014].

W niniejszym artykule do określenia konsekwencji „klątwy surowcowej” dla konkurencyjności Azerbejdżanu, Kazachstanu oraz Rosji w handlu międzynarodowym wykorzystano dwa wskaźniki, tj. wskaźnik ujawnionych przewag komparatywnych Balassy (RCA) [1965, 1989] oraz wskaźnik relacji eksportowo-importowych Lafaya (LFI) [1992].

Wartości pierwszego ze wskazanych powyżej wskaźników wyznaczono w oparciu o zlogarytmowaną oryginalną formułę B. Balassy [1965, 1989] według poniższego wzoru:

$$
R C A_{i j}^{K}=\ln \left(\frac{x_{i j}^{K}}{X_{j}^{K}} / \frac{x_{i}^{j}}{X^{j}}\right),
$$

gdzie: $R C A_{i j}^{K}$ - wskaźnik ujawnionych przewag komparatywnych kraju $K$ dla grupy towarowej $i$ w stosunku do kraju lub grupy krajów $j, x_{i j}^{K}$ - eksport grupy towarowej $i$ z kraju $K$ do kraju lub grupy krajów $j, X_{j}^{K}$ - eksport ogółem z kraju $K$ do kraju lub grupy krajów $j, x_{i}^{j}$ - eksport grupy towarowej $i$ z kraju lub grupy krajów $j, X^{j}$ - eksport ogółem z kraju lub grupy krajów $j, i$ - grupa towarowa, $K$ - analizowany kraj, $j$ - pozostałe kraje świata.

Użycie postaci logarytmicznej powyższej formuły pozwala na zachowanie symetryczności dodatnich i ujemnych wskaźników $R C A_{i j}^{K}$ w przedziale wahającym się wokół zera, co ułatwia ich interpretację [Vollrath 1991]. O występowaniu ujawnionej przewagi komparatywnej $\mathrm{w}$ handlu daną grupą towarową $i$ możemy mówić tylko wtedy, gdy jej udział w eksporcie danego kraju jest wyższy od udziału danej grupy towarowej $i$ w światowym eksporcie ogółem, a zatem gdy $R C A_{i j}^{K}>0$.

Z kolei wartości drugiego z wymienionych wskaźników - wskaźnika relacji eksportowo-importowych Lafaya [1992], stosowanego powszechnie do oceny charakteru salda obrotów handlowych danego kraju z zagranicą, a pośrednio także poziomu jego międzynarodowej konkurencyjności, wyznaczono zgodnie z poniższym wzorem:

$$
L F I_{i j}^{K}=100 \cdot\left(\frac{x_{i j}^{K}-m_{i j}^{K}}{x_{i j}^{K}+m_{i j}^{K}}-\frac{X_{j}^{K}-M_{j}^{K}}{X_{j}^{K}+M_{j}^{K}}\right) \cdot \frac{x_{i j}^{K}+m_{i j}^{K}}{X_{j}^{K}+M_{j}^{K}},
$$

gdzie: $L F I_{i j}^{K}$ - wskaźnik Lafaya kraju $K$ dla grupy towarowej $i$ w stosunku do kraju lub grupy krajów $j, x_{i j}^{K}$ - eksport grupy towarowej $i$ z kraju $K$ do kraju lub grupy krajów $j, X_{j}^{K}-$ eksport ogółem z kraju $K$ do kraju lub grupy krajów $j$, $m_{i j}^{K}-$ import grupy towarowej $i$ przez kraj $K$ z kraju lub grupy krajów $j, M_{j}^{K}$ - import ogółem przez kraj $K$ z kraju lub grupy krajów $j, i$ - grupa towarowa, $K$ - analizowany kraj, $j$ - pozostałe kraje świata. 
O występowaniu przewag komparatywnych w handlu zagranicznym danego kraju w tym przypadku mówimy, gdy wartości powyższego wskaźnika dla danej grupy towarowej $i$ są dodatnie $\left(L F I_{i j}^{K}>0\right)$, co oznacza, że dany kraj posiada nadwyżkę w handlu daną grupą towarową $i$.

W oparciu o wartości wskaźników RCA oraz LFI dla lat 2000-2016 dokonano sumarycznej oceny poziomu konkurencyjności Azerbejdżanu, Kazachstanu oraz Rosji w handlu międzynarodowym w zakresie czterech podstawowych grup towarów według klasyfikacji OECD, opartej na stopniu zaawansowania technologicznego. Zastosowanie takiego podejścia pozwala na ocenę poziomu międzynarodowej konkurencyjności tych krajów w zakresie towarów wysokiej, średnio-wysokiej, średnio-niskiej oraz niskiej techniki ${ }^{1}$ [OECD 2011; Hatzichronoglou 1997]. Dodatkowo sprawdzono, w jakim stopniu kraje te konkurencyjne są w międzynarodowym handlu paliwami mineralnymi, olejami i produktami ich destylacji, szczególnie istotnymi w kontekście „klątwy surowcowej”. Wszystkie niezbędne dane wykorzystane do analizy przedmiotowego zagadnienia pochodzą z bazy United Nations Commodity Trade Statistics Database.

\section{3. „Klątwa surowcowa” w Azerbejdżanie, Kazachstanie oraz Rosji - identyfikacja zjawiska}

O „klątwie surowcowej”, według R. Auty’ego [1993], możemy mówić, gdy w danym kraju co najmniej 8\% PKB wytwarzane jest przez przemysł wydobywczy, a także 40\% dochodów z eksportu pochodzi ze sprzedaży surowców. Z kolei R. Dobbs i in. [2013] zaproponowali swoją listę warunków, które muszą być spełnione, by można było zdiagnozować ,klątwę surowcową”. Po pierwsze, eksport surowców musi stanowić co najmniej $20 \%$ całkowitego eksportu danego kraju w danym roku, po drugie, przychody ze sprzedaży surowców powinny stanowić średnio co najmniej $20 \%$ przychodów budżetowych w 5 kolejnych latach i wreszcie po trzecie, renty surowcowe, rozumiane jako różnice pomiędzy kosztami wydobycia a ceną uzyskiwaną ze sprzedaży surowców na rynkach światowych, powinny stanowić co najmniej $10 \%$ PKB kraju w danym roku.

${ }^{1}$ Do grupy towarów wysokiej techniki OECD zalicza: statki powietrzne i kosmiczne, wyroby farmaceutyczne; maszyny biurowe i komputery; sprzęt i urządzenia radiowe, telewizyjne i telekomunikacyjne; instrumenty medyczne, precyzyjne i optyczne oraz zegary i zegarki. Do grupy towarów średnio-wysokiej techniki OECD zalicza: maszyny i aparaturę elektroniczną; pojazdy samochodowe, przyczepy i naczepy; wyroby chemiczne, z wyłączeniem wyrobów farmaceutycznych; lokomotywy kolejowe i tramwajowe, motocykle oraz rowery. Do grupy towarów średnio-niskiej techniki OECD zalicza: statki i łodzie; produkty rafinacji ropy naftowej i paliwa jądrowe; wyroby gumowe i z tworzyw sztucznych; metalowe wyroby gotowe (z wyjątkiem maszyn i urządzeń). Do grupy towarów niskiej techniki OECD zalicza: artykuły spożywcze i napoje, wyroby tytoniowe; wyroby włókiennicze; drewno i wyroby z drewna; papier i wyroby z papieru; meble. 
W przypadku wszystkich trzech analizowanych krajów, tj. Azerbejdżanu, Kazachstanu oraz Rosji, jednoznacznie należy stwierdzić, iż są one dotknięte zjawiskiem „klątwy surowcowej”. Spełniają bowiem wszystkie przedstawione powyżej warunki, aczkolwiek w nieco różnym stopniu.

Zdecydowanie najsilniej „,klątwą surowcową" z grona tych krajów dotknięty jest Azerbejdżan. Stopień uzależnienia tego kraju od posiadanych surowców znacznie przewyższa bowiem analogiczny dla Kazachstanu oraz Rosji. Dość powiedzieć, iż udział paliw mineralnych (ropy naftowej i gazu ziemnego) w PKB tego kraju po 2008 roku oscylował wokół 48-50\%, zaś w eksporcie aż bagatela 94-95\% (tabela 1). Co prawda identyczne wskaźniki dla Kazachstanu oraz Rosji były niższe aniżeli dla Azerbejdżanu, niemniej jednak także znacznie przewyższały stosowne progi wyznaczone przez Auty'ego oraz Dobbsa i in. Wahały się one w analogicznym okresie odpowiednio od $22 \%$ do $26 \%$ oraz od $50 \%$ do $57 \%$ w przypadku Kazachstanu, a także od $20 \%$ do $25 \%$ oraz od $50 \%$ do $53 \%$ w przypadku Rosji.

Tabela 1. Udział ropy naftowej oraz gazu ziemnego w PKB oraz eksporcie Azerbejdżanu, Kazachstanu oraz Rosji w latach 2002-2007 oraz 2008-2015

\begin{tabular}{|l|c|c|c|c|}
\hline \multirow{2}{*}{ Kraje } & \multicolumn{2}{|c|}{ Udział w PKB (\%) } & \multicolumn{2}{c|}{ Udział w eksporcie (\%) } \\
\cline { 2 - 5 } & $2002-2007^{*}$ & $2008-2015^{*}$ & $2002-2007^{*}$ & $2008-2015^{*}$ \\
\hline Azerbejdżan & $42-50$ & $48-50$ & $83-90$ & $94-95$ \\
\hline Kazachstan & $15-18$ & $22-26$ & $50-65$ & $50-57$ \\
\hline Rosja & $17-23$ & $20-25$ & $45-50$ & $50-53$ \\
\hline
\end{tabular}

* Maksymalne i minimalne wartości w danym okresie.

Źródło: [Kalyuzhnova, Zhukov 2014] oraz uzupełnienia własne na podstawie danych IMF i narodowych urzędów statystycznych.

Jeśli z kolei spojrzymy na znaczenie „renty surowcowej” dla trzech analizowanych gospodarek, to okaże się, iż również w tym przypadku warunek istnienia „klątwy surowcowej” jest spełniony (rys. 1). Jedynie w 2015 roku wartość „,renty surowcowej" (jako \% PKB) spadła poniżej wymaganego poziomu 10\% PKB w przypadku Kazachstanu i wyniosła wówczas 9,19\%. Zdecydowanie najwyższe dochody netto z tytułu wydobycia i sprzedaży posiadanych surowców, głównie paliw mineralnych (w odniesieniu do PKB), począwszy od 1990 roku aż po rok 2015, odnotowywano w Azerbejdżanie. W rekordowym pod tym względem 2007 roku wyniosły one aż 38,9\% PKB tego kraju. Dla porównania maksymalną ich wielkość odnotowano w Kazachstanie w 2008 roku na poziomie 27,6\% PKB, zaś w Rosji w 2000 roku na poziomie $21,7 \%$ PKB.

Warto także zwrócić uwagę z jednej strony na stosunkowo dużą fluktuację wielkości „rent surowcowych” w analizowanych krajach (zdecydowanie największa w przypadku Azerbejdżanu), z drugiej zaś na silne ich uzależnienie od koniunktury cenowej na międzynarodowych rynkach surowcowych. W tym kontekście zwraca 


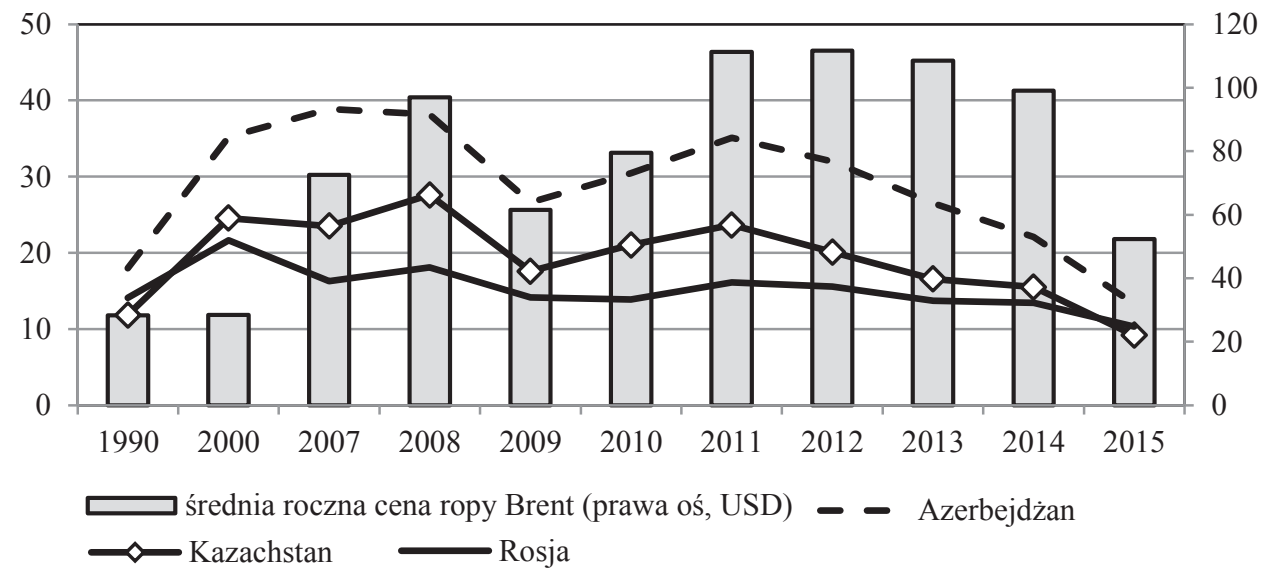

Rys. 1. „Renta surowcowa” jako proc. PKB w Azerbejdżanie, Kazachstanie oraz Rosji w wybranych latach okresu 1990-2015

Źródło: opracowanie własne na podstawie danych Banku Światowego.

uwagę przedstawiony na rysunku 1 gwałtowny spadek cen ropy naftowej w 2008 roku oraz stopniowy od 2011 roku i bardzo wyraźne tego konsekwencje dla wielkości „rent surowcowych” w analizowanych krajach. Powyższa sytuacja najdobitniej pokazuje słabość modelu funkcjonowania i rozwoju w oparciu o posiadane surowce, uzależnia to bowiem kondycję makroekonomiczną danego kraju od koniunktury cenowej na międzynarodowych rynkach surowcowych [Falkowski 2017a].

\section{Długookresowe przewagi komparatywne Azerbejdżanu, Kazachstanu oraz Rosji w handlu zagranicznym w latach 2000-2016}

Z przeprowadzonej analizy kształtowania się ujawnionych długookresowych przewag komparatywnych w handlu zagranicznym Azerbejdżanu, Kazachstanu oraz Rosji w latach 2000-2016 jednoznacznie wynika, iż wszystkie te kraje są bardzo konkurencyjne na arenie międzynarodowej w zakresie handlu paliwami mineralnymi, a także olejami i produktami ich destylacji (o czym świadczą wysokie i dodatnie wartości wskaźników RCA oraz LFI). W całym badanym okresie najwyższą konkurencyjnością w tym zakresie charakteryzowała się gospodarka azerska, następna w kolejności była gospodarka kazachska i dopiero na trzecim miejscu w gronie tych krajów gospodarka rosyjska (rys. 2). Należy wyraźnie podkreślić, iż zidentyfikowane powyższe przewagi są de facto pochodną geograficznego rozmieszczenia złóż surowców mineralnych na świecie, w konsekwencji kraje posiadające duże zasoby tych surowców w oczywisty sposób mają w handlu nimi naturalne przewagi komparatywne w stosunku do pozostałych krajów świata. 
Wskaźnik RCA (Balassy)

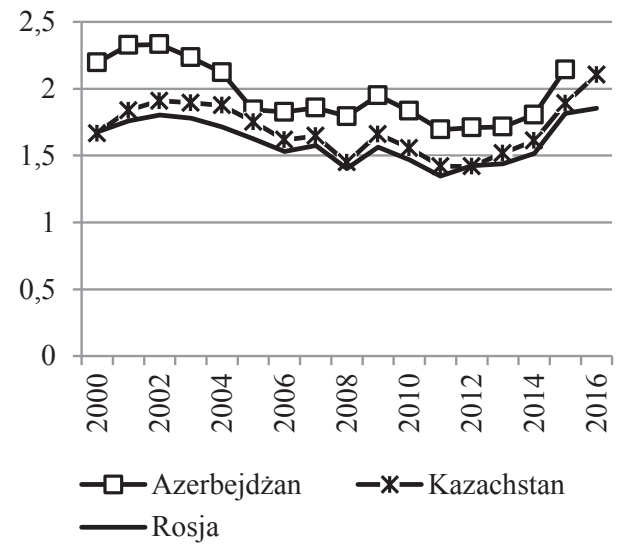

Wskaźnik LFI (Lafaya)

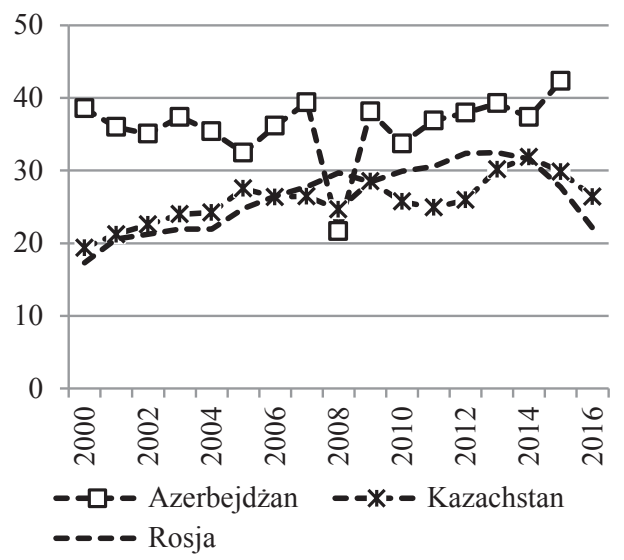

Rys. 2. Ujawnione przewagi komparatywne Azerbejdżanu, Kazachstanu oraz Rosji w handlu paliwami mineralnymi, olejami i produktami ich destylacji w latach 2000-2016

Źródło: opracowanie własne na podstawie danych United Nations Commodity Trade Statistics Database.

Analizując wyniki przedmiotowej analizy z uwzględnieniem czterech podstawowych grup towarów według stopnia ich zaawansowania technologicznego, zgodnie ze stosowną klasyfikacją OECD (zob. rys. 3), należy jednoznacznie stwierdzić, iż wszystkie te kraje są konkurencyjne w handlu międzynarodowym jedynie w zakresie grupy towarów średnio-niskiej techniki, w której znajdują się także surowce $\mathrm{i}$ ich pochodne. Najwyższą konkurencyjnością w tym zakresie charakteryzowała się w badanym okresie Rosja, o czym świadczą najwyższe wartości wskaźników RCA oraz LFI. Także Kazachstan, aczkolwiek z pewnymi małymi wyjątkami, utrzymywał posiadane w tym zakresie ujawnione przewagi komparatywne. Nie można tego powiedzieć o Azerbejdżanie, w przypadku którego wyraźnie widoczny był spadek międzynarodowej konkurencyjności w handlu tą grupą towarów po 2008 roku, czego egzemplifikacją były ujemne wartości wskaźników RCA oraz LFI w tym okresie. Jest to o tyle ciekawe, że w tym samym czasie konkurencyjność Azerbejdżanu w handlu paliwami mineralnymi, olejami i produktami ich destylacji nie spadła, a wręcz wzrosła. Głównym powodem jednak takiej sytuacji był znaczny (wręcz dramatyczny) spadek konkurencyjności azerskiej gospodarki w zakresie produkcji statków i łodzi, a także, aczkolwiek w nieco mniejszym stopniu, w zakresie handlu wyrobami gumowymi oraz z tworzyw sztucznych, które również wchodzą w skład grupy towarów średnio-niskiej techniki.

O tym, iż ogólny poziom międzynarodowej konkurencyjności Azerbejdżanu, Kazachstanu oraz Rosji jest niski, a należy wiązać to przede wszystkim z surowcowym charakterem ich gospodarek, świadczy fakt, iż wszystkie te gospodarki nie posiadają 

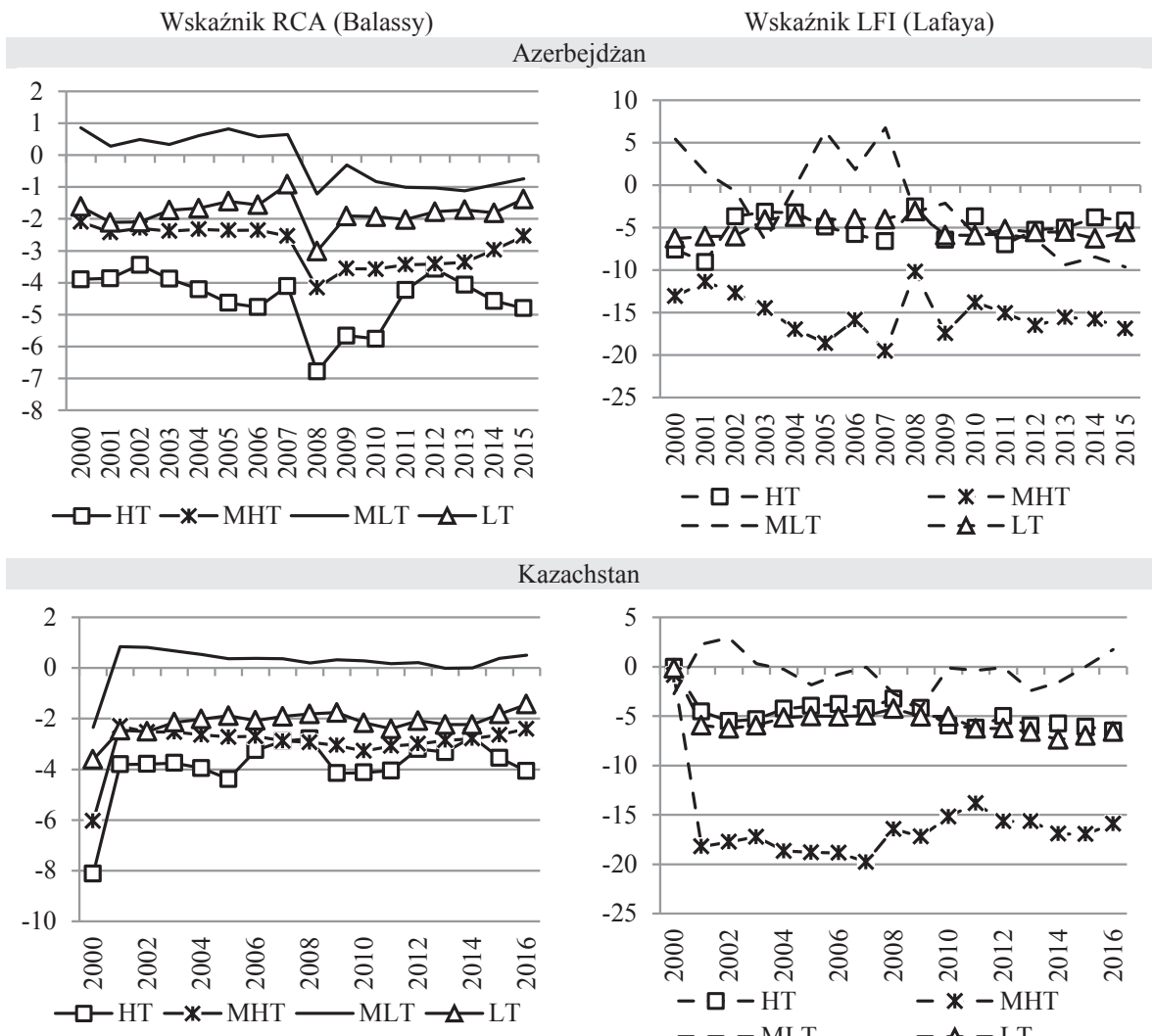

hstan
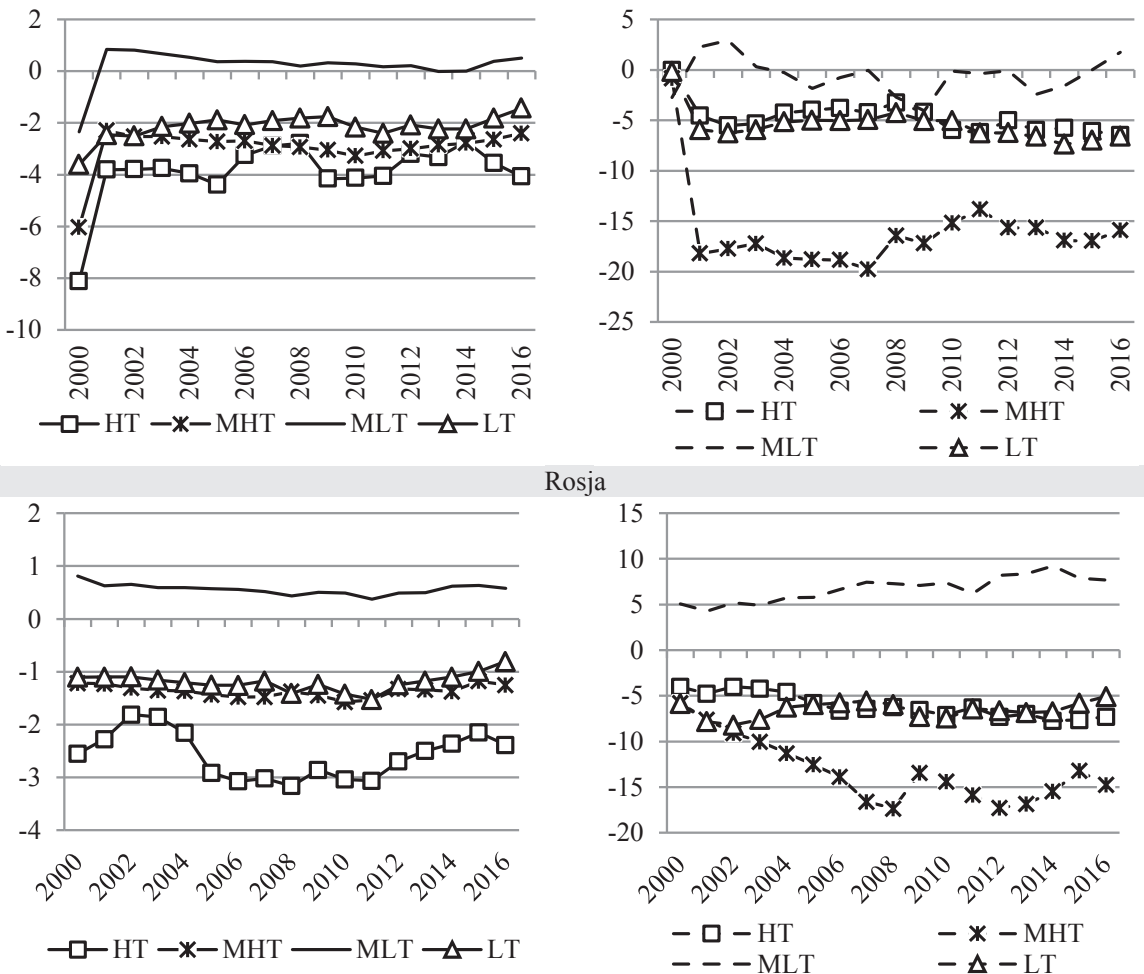

Rosja

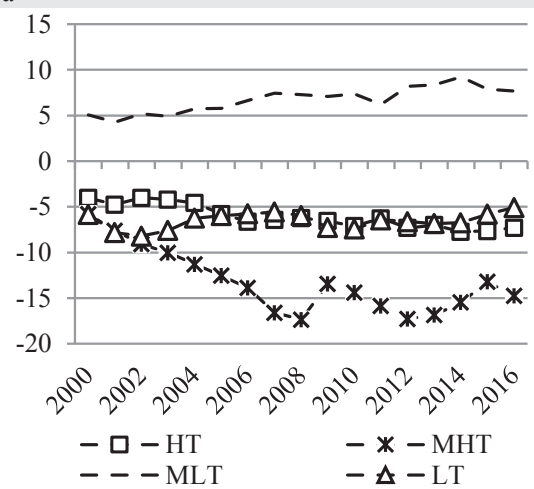

* HT - towary wysokiej techniki, MHT - towary średnio-wysokiej techniki, MLT - towary średnio-niskiej techniki, LT - towary niskiej techniki

Rys. 3. Ujawnione przewagi komparatywne Azerbejdżanu, Kazachstanu oraz Rosji w zakresie handlu towarami wysokiej, średnio-wysokiej, średnio-niskiej oraz niskiej techniki w latach 2000-2016

Źródło: opracowanie własne na podstawie danych United Nations Commodity Trade Statistics Database. 
żadnych ujawnionych przewag komparatywnych w zakresie handlu towarami z grup wysokiej, średnio-wysokiej, a nawet niskiej techniki ogółem. Szczególnie niekorzystna sytuacja z punktu widzenia ich dalszego rozwoju społeczno-gospodarczego odnosi się nie tylko do samego braku konkurencyjności w zakresie handlu towarami o wysokim stopniu zaawansowania technologicznego, ale co więcej, jak wynika z przeprowadzonej szczegółowej analizy ich handlu zagranicznego, braku poprawy sytuacji w tym zakresie (czego dowodem jest brak poprawy wartości stosownych wskaźników RCA oraz LFI). Trudno tego nie łączyć z „klątwą surowcową” i jej negatywnymi konsekwencjami, które prowadzą do ugruntowania międzynarodowej specjalizacji tych gospodarek $\mathrm{w}$ handlu paliwami mineralnymi i ich pochodnymi, $\mathrm{z}$ drugiej strony jednakże zwiększając $\mathrm{w}$ oczywisty sposób ich zależność od koniunktury cenowej na międzynarodowych rynkach surowcowych.

\section{Zakończenie}

Z przeprowadzonej analizy jednoznacznie wynika, iż gospodarki Azerbejdżanu, Kazachstanu oraz Rosji są dotknięte zjawiskiem „klątwy surowcowej”, aczkolwiek w różnym stopniu. Zdecydowanie najsilniej „klątwą surowcową” z grona tych krajów dotknięty jest Azerbejdżan, w przypadku którego stopień uzależnienia dochodu narodowego od wydobycia i sprzedaży posiadanych surowców mineralnych znacznie przewyższa analogiczny dla Kazachstanu oraz Rosji.

Fakt występowania „klątwy surowcowej” w tych krajach i w konsekwencji prowadzone od lat polityki gospodarcze wzmacniające tylko surowcowy charakter ich gospodarek obniżają niestety wymiernie ogólny poziom międzynarodowej konkurencyjności tych krajów. W efekcie ogólny poziom konkurencyjności Azerbejdżanu, Kazachstanu oraz Rosji w handlu międzynarodowym jest niski, a w przypadku towarów wysokiej oraz średnio-wysokiej techniki wręcz dramatycznie niski. Jedyne przewagi komparatywne kraje te (z wyjątkiem Azerbejdżanu od 2008 roku) posiadały w analizowanym okresie $\mathrm{w}$ eksporcie towarów z grupy średnio-niskiej techniki (zwłaszcza surowców mineralnych i ich pochodnych). Z punktu widzenia dalszego ich rozwoju gospodarczo-społecznego jest to sytuacja niezwykle niekorzystna, uzależnia bowiem ów rozwój od koniunktury cenowej na międzynarodowych rynkach surowcowych.

Największa świadomość wynikających z tego faktu zagrożeń występuje w przypadku Kazachstanu [Falkowski 2017b], gdzie w ostatnich latach władze tego kraju podjęły szereg konkretnych działań na rzecz zmiany istniejącego profilu konkurencyjnego [The strategic plan... 2010]. Niestety, takich działań nie widać w Azerbejdżanie ani w Rosji. 


\section{Literatura}

Auty R.M., 1993, Sustaining Development in Mineral Economies: The Resource Curse Thesis. Routledge, London.

Balassa B., 1965, Trade liberalization and 'revealed' comparative advantage, The Manchester School of Economic and Social Studies, vol. 33, no. 2, s. 99-123.

Balassa B., 1989, 'Revealed' comparative advantage revisited, [w:] Balassa B. (ed.), Comparative Advantage, Trade Policy and Economic Development, New York University Press, New York, s. 63-79.

Carbaugh R., 2017, International Economics, Cengage, Boston.

Dobbs R., Oppenheim J., Kendall A., Thompson F., Bratt M., van der Marel F., 2013, Reverse the Curse: Maximizing the Potential of Resource-Driven Economies, McKinsey Global Institute, London.

Falkowski K., 2017a, Long-term comparative advantages of the Eurasian Economic Union member states in international trade, International Journal of Management and Economics, vol. 53, issue 4, s. 27-49.

Falkowski K., 2017b, The resources-dependent competitive profile of Kazakhstan and its consequences for the country's future development, Prace Naukowe Uniwersytetu Ekonomicznego we Wrocławiu, nr 486, s. 92-102.

Gylfason T., Herbertsson T.T., Zoega G., 1999, A mixed blessing: Natural resources and economic growth, Macroeconomic Dynamics, vol. 3, s. 204-225.

Hatzichronoglou T., 1997, Revision of the high technology sector and product classification, STI Working Papers 1997/2, OECD/GD 97(216), Organisation for Economic Co-operation and Development, Paris.

Humphreys M., Sachs J.D., Stiglitz J.E., 2007, Escaping the Resource Curse, Columbia University Press, New York.

Kalyuzhnova Y., Zhukov S., 2014, Kazakhstan: the Best Oil and Gas Magnate in the CIS?, https:// www.aeaweb.org/conference/2014/retrieve.php?pdfid=277 (12.09.2017).

Lafay G., 1992, The Measurement of Revealed Comparative Advantages, [w:] Dagenais M.G., Muet P.A. (eds.), International Trade Modeling, Chapman \& Hill, London.

OECD, 2011, ISIC Rev. 3 Technology intensity definition. Classification of manufacturing industries into categories based on R\&D intensities, http://www.oecd.org/sti/ind/48350231.pdf(13.07.2017).

Sachs J. D., Warner A.M., 1995, Natural Resource Abundance and Economic Growth, National Bureau of Economic Research Working Paper, no. 6398, Cambridge.

Sachs J.D., Warner A.M., 1997, Natural Resource Abundance and Economic Growth, Cambridge, MA: HIID mimeo, http://www.cid.harvard.edu/ciddata/warner_files/natresf5.pdf (24.08.2017).

Sachs J.D., Warner A.M., 2001, Natural resources and economic development. The curse of natural resources, European Economic Review, vol. 45, s. 827-838.

Startiene G., Remeikiene R., 2014, Evaluation of revealed comparative advantage of Lithuanian industry in global markets, Procedia - Social and Behavioral Sciences, vol. 110, s. 428-438.

Stiglitz J.S., 2006, Making Globalization Work. The Next Steps to Global Justice, Penguin, London.

The strategic plan for development of the Republic of Kazakhstan until the year 2020, 2010, http:// www.amu.kz/en/helpful/Kazakhstan_s_strategic_development_plan-2020.PDF (12.09.2017).

Vollrath T., 1991, A theoretical evaluation of alternative trade intensity measures of revealed comparative advantage, Review of World Economics, vol. 127, no. 2, s. 265-280.

Weresa M.A. (ed.), 2014, Innovation, Human Capital and Trade Competitiveness. How Are They Connected and Why Do They Matter?, Springer International Publishing, Switzerland.

Wu J., Ma Z., Zhuo S., 2017, Enhancing national innovative capacity: The impact of high-tech international trade and inward foreign direct investment, International Business Review, vol. 26, no. 3 , s. 502-514. 